\title{
ダイズ斑点細菌病菌における培地中とジャガイモ塊茥上での コロナチン産生の違い*
}

\author{
森脇 丈治 ${ }^{* *}$ ・水野 明文 ${ }^{* *+}$ ・佐藤 守 ${ }^{* * *}$ ・閒田 育生 ${ }^{* *}$ ・西山 幸司 ${ }^{* *}$ \\ Jouji MoriwaKiı**, Akifumi Mizuno**,t, Mamoru Sato***, Ikuo Kadota** and Koushi NishiYama**: \\ Difference in Production of Coronatine on Potato Tuber Tissue and in Liquid Culture \\ by Pseudomonas syringae pv. glycinea
}

\begin{abstract}
Twenty-five strains of Pseudomonas syringae pv. glycinea were studied for their ability to produce coronatine and symptoms on soybean leaves. Seven strains induced lesions accompanied by halos on soybean leaves after natural and artificial infection, whereas the other strains induced lesions without halos. Five of the seven halo-inducers also produced coronatine on potato tuber tissues, whereas the 18 non-halo inducing strains did not. However, all 25 strains produced coronatine in Woolley's liquid medium. In addition, all twenty-five strains had a pCOR1-like plasmid in size. The $c f$ region in pCOR1, which is correlated with coronatine production in $P$. syringae pv. atropurpurea, was also detected in the pCOR1-like plasmids in all 25 strains. These results indicate that $P$. syringae pv. glycinea essentially has coronatine-producing ability, but its expression in planta may be regulated by a control system.
\end{abstract}

Key words : Pseudomonas syringae pv. glycinea, bacterial blight, soybean, coronatine, potato hypertrophy assay, pCOR1.

ダイズ斑点細菌病（病原：Pseudomonas syringae pv. glycinea (Coerper 1919) Young, Dye \& Wilkie 1978)

は,ダイズの重要病害のひとつであり，世界中に広く分布 している ${ }^{13)}$ 。本菌にはダイズ葉にハローを形成するもの (ハロー形成菌)とハローを形成しないもの（ハロー非形成 菌）とがある ${ }^{3,6,8)}$ (Fig. 1)。八ロー形成菌によって生じる 病斑では，水浸状斑点の周囲に退緑した部分（ハロー）が 形成されるが，八ロー非形成菌によって生じる病斑では退 緑部分がない。また, 先の研究で, 菌体をジャガイモ塊茥 切片に直接接種し, ジャガイモ細胞の肥大の有無でコロナ

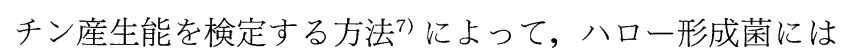
コロナチン産生能があること采, およびコロナチンの希薄 溶液をダイズ葉に処理すると, 病原細菌の接種で生じる八 ローと類似した薬斑を生じること7)が明らかにされてい る。これらのことから, コロナチンを産生する菌が八ロー 病斑を形成すると推察された ${ }^{8}$ 。しかし, ブラジル産のダイ ズ斑点細菌病菌を同定する過程で, ブラジル産菌の一部は ハローのある病斑を形成するにもかかわらず, ジャガイモ 法ではコロナチンは検出されなかった ${ }^{9)}$ 。この結果は, 本菌 のコロナチン産生能とハロー形成能との直接的関係を疑
わせるものである。そこで, ダイズ斑点細菌病菌のコロナ チン産生能と病徵型との関係を明確にするため, 培地中と ジャガイモ塊茎上でのコロナチン産生について調査し, 併せてコロナチン産生に関係するプラスミドの有無を調 ベた。

試験に供したダイズ斑点細菌病菌は, pathotype strain, ブラジル産のハロー形成菌 2 株, ハロー非形成菌 1 株, 日 本産のハロー形成菌 4 株, ハロー非形成菌 17 株で, いずれ も農林水産省微生物ジーンバンク (MAFF) 所蔵株である (Table 1)。対照には，コロナチン発見の元になったイ夕 リアンライグラスかさ枯病細菌 P. s. pv. atropurpurea MAFF 301309 を用いた。病原性およびハロー形成の有無 は以下の方法で調べた。ダイズ (品種：鶴の子, 播種後 4 週 間) に細菌懸濁液 $\left(10^{8} \mathrm{cfu} / \mathrm{ml}\right)$ を噴霧接種し， $25^{\circ} \mathrm{C} の$ 湿室 に 24 時間置いたのち $25^{\circ} \mathrm{C}$ のガラス室に移して 5 日後に 観察した。

コロナチンの抽出は西山防に準じ以下の方法で行った。 Woolley らの培地 ${ }^{15)} 150 \mathrm{ml}$ に供試細菌を移植し, $23^{\circ} \mathrm{C}$ で 5 日間振とう培養 $(130 \mathrm{rpm})$ したのち, 遠心分離 $(12,000 \times g$, 10 分）によって上清を回収し， $1 \mathrm{~N}$ 塩酸で $\mathrm{pH} 3$ に調整

* 本研究の概要は平成 7 年度日本植物病理学会大会で発表した。

** 農業環境技術研究所 National Institute of Agro-Environmental Sciences, Tsukuba 305, Japan

*** 虫糸・昆虫農業技術研究所 National Institute of Sericultural and Entomological Science, Tsukuba 305, Japan

$\dagger$ 現在 : 横浜植物防疫所 Present address: Yokohama Plant Protection Station, Yokohama 231, Japan 


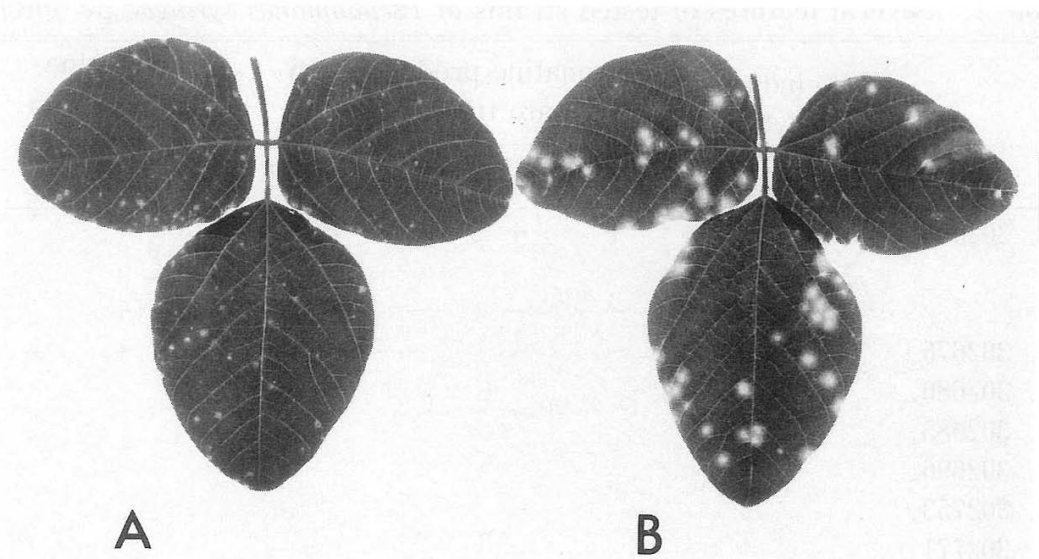

Fig. 1. Leaflet symptoms of soybean, inoculated with Pseudomonas syringae pv. glycinea. A : Inoculated with MAFF 302677 strain causing symptoms without halo. B : Inoculated with MAFF 301683, a halo-inducing strain.

Table 1. Tested strain

\begin{tabular}{|c|c|c|c|c|}
\hline Strain & Locality & Host & $\begin{array}{l}\text { Year and month } \\
\text { isolated }\end{array}$ & Reference \\
\hline \multicolumn{5}{|l|}{$\begin{array}{l}\text { Pseudomonas syringae } \\
\text { pv. glycinea }\end{array}$} \\
\hline MAFF $302260^{\text {PT }}$ & New Zealand & Soybean & 1968.3 & - \\
\hline 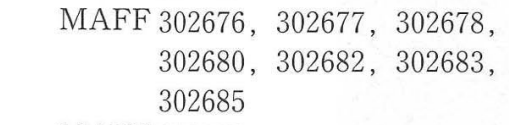 & Iwate, Japan & Soybean & 1981.9 & 8) \\
\hline MAFF 302688 & Akita, Japan & Soybean & 1981.9 & 8) \\
\hline $\begin{array}{c}\text { MAFF } 301683, \quad 302690,302691, \\
302694, \quad 302696\end{array}$ & Ibaraki, Japan & Soybean & 1981.9 & 8) \\
\hline $\begin{array}{l}\text { MAFF } 302751,302752,302753, \\
302754\end{array}$ & Ibaraki, Japan & Soybean & 1982.7 & 8) \\
\hline MAFF $302770,302771,302772$ & Ibaraki, Japan & Soybean & 1982.9 & 8) \\
\hline MAFF 301765 & Ibaraki, Japan & Soybean & 1982.9 & - \\
\hline MAFF 210373, 210381 & Bahia, Brazil & Soybean & 1989.2 & 9) \\
\hline MAFF 210396 & Brasilia DF, Brazil & Soybean & 1989.3 & 9) \\
\hline \multicolumn{5}{|l|}{ pv. atropurpurea } \\
\hline MAFF 301309 & Chiba, Japan & Italian ryegrass & 1971.7 & 7) \\
\hline
\end{tabular}

PT : Pathotype strain. MAFF : Ministry of Agriculture, Forestry and Fisheries of Japan.

し，酢酸エチルで 3 回抽出した。酢酸エチル相を分取し て $40^{\circ} \mathrm{C}$ 減圧下で濃縮・乾固し, 残渣を $1.5 \mathrm{ml}$ のアセトン に溶解して 100 倍濃縮液とした。この抽出液中のコロナチ ンの有無はジャガイモ塊茎によって生物検定した。ジャガ イモは塊菱 (品種：男爵) を直径 $10 \mathrm{~mm}$ 厚さ $8 \mathrm{~mm}$ の円柱 形に切り取り, 流水で 30 分間洗浄したものを用いた。直径 $6 \mathrm{~mm}$ の抗生物質検定用ろ紙 (東洋ろ紙) に抽出液を $10 \mu \mathrm{l}$ 吸収させて風乾したのち，ジャガイモ塊茥切片上に置き， その上に滅菌水を $20 \mu \mathrm{l}$ 滴下した。このジャガイモ塊茎切 片を湿らせたろ紙を敷いたシャーレに入れ, $25^{\circ} \mathrm{C} て ゙ 5$ 日間 静置したのち, 接触面の隆起を肉眼観察し, 併せてジャガ イモ細胞の肥大の有無を実体顕微鏡で拡大して調べた。そ の結果，供試細菌 25 株のすべてでジャガイモ細胞の肥大 がみられ，コロナチン産生能が確認された。次に，これら 菌株の細菌体を直接ジャガイモに接種し，20,23,26, $29^{\circ} \mathrm{C}$ の 4 段階で培養してコロナチン産生能を検定した。すべて
の培養温度に挄てて，5株のハロー形成菌からはコロナチ ンが檢出されたが，残りの 2 株のハロー形成菌（ブラジル 産菌）と18株の八ロー非形成菌からはコロナチンは検出 されなかった (Table 2)。

ライグラス類かさ枯病細菌では $88 \mathrm{~kb}$ のプラスミドが コロナチン産生に深く関係しており，このプラスミドは pCOR1 と命名されている ${ }^{12)}$ 。供試細菌のプラスミドをア ルカリ法1,11)で抽出し，0.9\%アガロースゲル電気泳動によ りプラスミドの有無を調べた。ダイズ斑点細菌病菌は複数 のプラスミドを保有しており，プラスミドパターンで 11 群に類別できた。各群のプラスミドパターンを Fig. 2 に示 した。図中のダイズ斑点細菌病菌のすべての株において， pCOR1 と同等の大きさ $(88 \mathrm{~kb}$ 前後 $)$ のプラスミドが認め られた。また，図示していないその他の 14 株においても pCOR1 と同等の大きさのプラスミドが認められた。

Bereswill ら²) はコロナチン産生に関与する遺伝子の一 
Table 2. Several features of tested strains of Pseudomonas syringae pv. glycinea

\begin{tabular}{|c|c|c|c|c|c|c|c|c|}
\hline \multirow[t]{2}{*}{ Strain } & \multirow{2}{*}{$\begin{array}{l}\text { Halo-inducing } \\
\text { on soybean } \\
\left(25^{\circ} \mathrm{C}\right)^{\text {a) }}\end{array}$} & \multicolumn{4}{|c|}{$\begin{array}{l}\text { Coronatine production on } \\
\text { potato tuber tissue }\end{array}$} & \multirow{2}{*}{$\begin{array}{l}\text { Coronatine } \\
\text { production in } \\
\text { liquid medium } \\
\left(23^{\circ} \mathrm{C}\right)\end{array}$} & \multirow{2}{*}{$\begin{array}{c}\text { pCOR1-like } \\
\text { plasmid } \\
\text { in size }\end{array}$} & \multirow{2}{*}{$\begin{array}{l}\text { PCR } \\
\text { signal }^{\mathrm{b}}\end{array}$} \\
\hline & & $\left(20^{\circ} \mathrm{C}\right)$ & $\left(23^{\circ} \mathrm{C}\right)$ & $\left(26^{\circ} \mathrm{C}\right)$ & $\left(29^{\circ} \mathrm{C}\right)$ & & & \\
\hline $\begin{array}{c}\text { MAFF } 301683, \quad 302260,302690, \\
302691,302772\end{array}$ & + & + & + & + & + & + & + & + \\
\hline MAFF 210373,210381 & + & - & - & - & - & + & + & + \\
\hline 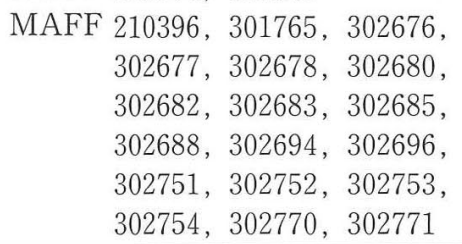 & - & - & - & - & - & + & + & + \\
\hline
\end{tabular}

a) Temperature cultured.

b) PCR was performed to amplify a portion of $c f^{2}$, which encoded the enzyme responsible for amide bond formation between coronafacic acid and coronamic acid.

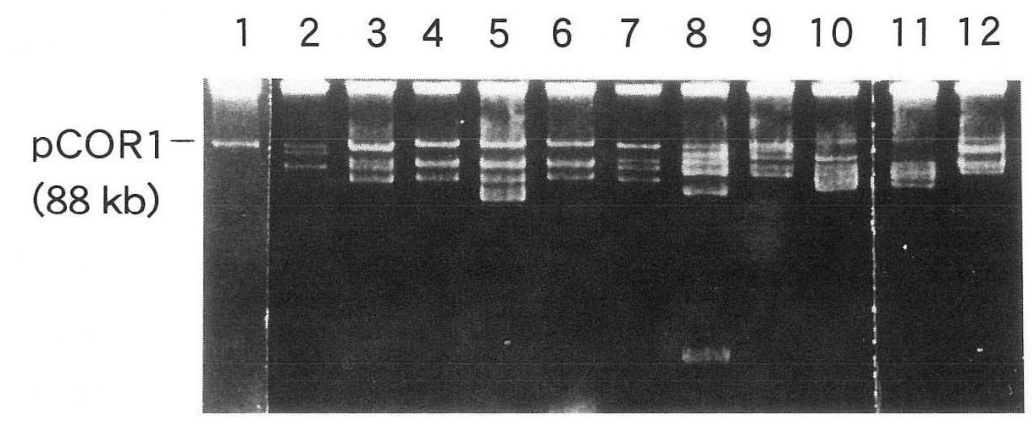

Fig. 2. Agarose gel electrophoresis of plasmid DNA in two coronatine-producing pathovars of Pseudomonas syringae. Lane 1 : P. s. pv. atropurpurea MAFF 301309 (pCOR 1). Lanes 2-12: P. s. pv. glycinea, 2 : MAFF 302260, $3:$ MAFF 301683, 4 : MAFF 302682, 5 : MAFF 302677, 6 : MAFF 302676, 7 : MAFF 302694, 8 : MAFF 302696, 9 : MAFF 302751, 10 : MAFF 210373, 11 : MAFF 210381, 12 : MAFF 210396.

部として, cfl 領域を報告している。それによると,コロナ チンはコロナファシン酸とコロナミン酸との結合により 合成され， $c f$ 領域はこの結合に関与しているとしている。 そして, このcfl領域は 5 つの病原型, P. s. pv. atropurpurea, P. s. pv. glycinea, P. s. pv. maculicola, P. s. pv. morsprunorum, P. s. pv. tomato のコロナチン産生能を 持つ株のみが保有していることを PCR (Polymerase Chain Reaction)法を用いて明らかにした。また, Zhu ら ${ }^{16)}$ も P. s. pv. maculicola のコロナチン産生能を持つ株のみ から同領域を検出している。供試細菌がこの領域を保有し ているかどうかを調べるために， $c f$ 領域に特有な配列を 増幅するプライマー（5'-GGCGCTCCCTCGCACTT-3'， 5'-GGTATTGGCGGGGGTGC-3') 2) を用い，それぞれか ら抽出したプラスミド DNAをテンプレートとして PCR 法により調べた。反応は, ASTEC社の PROGRAM TEMP CONTROL SYSTEM PC-700を使い, DNA 変 性 $94^{\circ} \mathrm{C} 1$ 分, アニーリング $55^{\circ} \mathrm{C} 2$ 分, DNA 伸長 $72^{\circ} \mathrm{C} 3$ 分 を 1 サイクルとして，30サイクル行った。得られた PCR 産物を $1 \%$ アガロースゲル電気泳動により調査した。その $\begin{array}{lllllllllll}1 & 2 & 3 & 4 & 5 & 6 & 7 & 8 & 9 & 10 & 1112\end{array}$

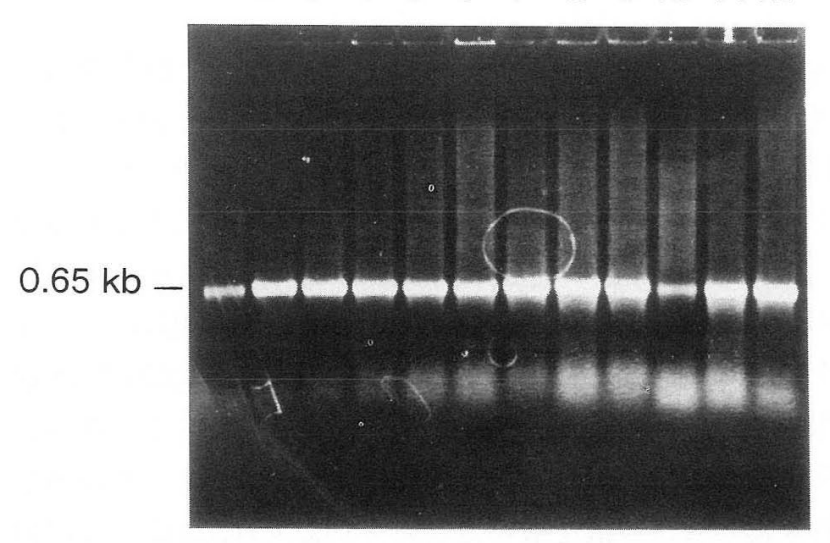

Fig. 3. PCR products amplified from Pseudomonas syringae. Lane 1: P. s. pv. atropurpurea MAFF 301309. Lanes 2-12: P. s. pv. glycinea, 2: MAFF 302260, 3: MAFF 301683, 4: MAFF 302682, 5: MAFF 302677, 6: MAFF 302676, 7 : MAFF 302694, 8: MAFF 302696, 9: MAFF 302751, 10 : MAFF 210373, 11 : MAFF 210381, 12 : MAFF 210396. 
結果，対照の MAFF 301309 株で認められた $c f$ 領域に特 異的な $0.65 \mathrm{~kb}$ のCR 産物は, すべてのダイズ斑点細菌 病菌において検出された（Fig. 3)。この PCR 産物を制限 酵素 SmaI，あるいは $\mathrm{ClaI}$ で切断すると，共に Bereswill $ら^{2)}$ の報告と同じ大きさの切断片が得られた。以上より, 供試細菌のすべてがコロナチン産生遺伝子群の一部であ る $c f l$ 領域を保有することは明らかである。

この $c f l$ 領域の存在場所を調べる目的で, 対照株 MAFF 301309 由来の $0.65 \mathrm{~kb}$ の PCR 産物をプローブとしてサザ ンハイブリダイゼーション ${ }^{11)}$ を行った。供試細菌のプラス ミドを $0.9 \%$ アガロースゲル電気泳動により分画し,アル カリブロッティング法10)により Hybond-N ナイロン膜 （アマシャム社）上に転写した。プローブの標識とハイブ リッドの検出はDNA ラベリング \& デテクションキッ トDIG-ELISA（ベーリンガー・マンハイム社）を用いた。 プローブの標識はランダムプライミング法4)により，八イ ブリッドの検出は酵素免疫測定法で行った。その結果, 標 識した $0.65 \mathrm{~kb}$ の PCR 産物のプローブはダイズ斑点細菌 病菌の全供試株の PCOR1 相当の大きさの最大プラスミド とだけ反応した。

以上の結果を要約すると Table 2 亿示す通りとなる。ダ イズ玨点細菌病菌においては, 1) 供試細菌の全株が液体培 地中でコロナチンを産生する能力を有する。2）供試細菌 の全株が pCOR1 相当の大きさのプラスミドを保有してい る。3）供試細菌のもつプラスミド中に pCOR1 亿存在する $c f l$ 領域と同等の配列がある。4) 供試細菌は細菌体を直接 ジャガイモに接種する方法では, コロナチンを産生して ジャガイモに細胞肥大を起こす株と, コロナチンを産生せ ず細胞肥大を起こさない株とに分けられる。5）ジャガイモ 塊茎上でのコロナチン産生の有無は, $20 \sim 29^{\circ} \mathrm{C}$ の間では培 養温度に影響されない。6）ダイズ（品種：鶴の子）への噴 霧接種で, 供試細菌は八ローを伴う病斑を形成する株と八 ローを伴わない病斑を形成する株とに分けられる。病斑に おける八ローの有無と,4) で述べたジャガイモ細胞の肥大 との関係をみると, 八ロー病斑を作りジャガイモ細胞を肥 大させる 5 株, ハロー病斑を作りジャガイモ細胞を肥大さ せない 2 株, ハローのない病斑を作りジャガイモ細胞を肥 大させない 18 株に分かれた。これとは別に，コロナチンを 産生しない株, 2,5,14), コロナチン産生遺伝子を持たない株2,14) が報告されているが，供試細菌にはそのような株はなかっ た。

この結果から，ダイズ斑点細菌病菌は，コロナチン産生 遺伝子を有し，その一部は少なくどもプラスミド上に存在 する。そして, コロナチン産生遺伝子は, Woolley らの液 体培地中ではいつでも発現するが, ジャガイモ塊茎上やダ イズ葉中ではその発現を制御している系があるのではな いかと推察される。

\section{引用文献}

1. Birnboim, H.C. and Doly, J. (1979). A rapid alkaline extraction procedure for screening recombinant plasmid DNA. Nucleic Acids Res. 7 : 1513-1523.

2. Bereswill, S., Bugert, P., Völksch, B., Ullrich, M., Bender, C.L. and Geider, K. (1994). Identification and relatedness of coronatine producing Pseudomonas syringae pathovars by PCR analysis and sequence determination of the amplification products. Appl. Environ. Microbiol. 60 : 2924-2930.

3. Chamberlain, D.W. (1952). A halo-producing strain of Pseudomonas glycinea. Phytopathology $42: 299-300$.

4. Feinberg, A.P. and Vogelstein, B. (1983). A technique for radiolabelling DNA restriction endonuclease fragments to high specific activity. Anal. Biochem. 132: 6-13.

5. Mitchell, R.E. (1982). Coronatine production by some phytopathogenic pseudomonads. Physiol. Plant Pathol. $20: 83-89$.

6. Moffett, M.L. (1976). A halo-producing strain of Pseudomonas glycinea in Australia. Rev. Plant Pathol. $55: 968$.

7. 西山幸司 (1981)。 ライグラス類かさ枯病細菌における 病原性関連物質に関する研究。農技研報 C 35: 1-55.

8. 西山幸司・畔上耕児・長田 茂・中曽根渡・江塚昭典・渡 辺康正 (1986). ダイズ細菌病の種類と病原細菌の同定. 農環研報 $1: 83-94$.

9. 西山幸司・Charchar, M.J.・飯塚典男 (1990)。 ブラジル のダイズ細菌病について。 日植病報 $56: 151$ (講要)。

10. Reed, K.C. and Mann, D.A. (1985). Rapid transfer of DNA from agarose gels to nylon membranes. Nucleic Acids Res. 13: 7201-7221.

11. Sambrook, J., Fritsch, E.F. and Maniatis, T. (1989). Molecular Cloning: A Laboratory Manual, Cold Spring Harbor Laboratory, New York.

12. Sato, M., Nishiyama, K. and Shirata, A. (1983). Involvement of plasmid DNA in the productivity of coronatine by Pseudomonas syringae pv. atropurpurea. Ann. Phytopathol. Soc. Jpn. 49 : 522-528.

13. Sinclair, J.B. and Backman, P.A. (1983). Compendium of Soybean Disease, 3rd ed., APS Press, Minnesota.

14. Ullrich, M., Bereswill, S., Völksch, B., Fritsche, W. and Geider, K. (1994). Molecular characterization of field isolates of Pseudomonas syringae pv. glycinea differing in coronatine production. J. Gen. Microbiol. 139: 1927-1937.

15. Woolley, D.W., Pringle, R.B. and Braun, A.C. (1952). Isolation of the phytopathogenic toxin of Pseudomonas tabaci, an antagonist of methionine. J. Biol. Chem. 197 : 409-417.

16. Zhu, Y., Tamura, K., Watanabe, M., Matsuda, I. and Sato, M. (1995). Plasmid-mediated coronatine production in Pseudomonas syringae pv. maculicola. Ann. Phytopathol. Soc. Jpn. 61: 569-574.

(平成 8 年 4 月 11 日受付; 平成 8 年 7 月 23 日受理) 